\title{
The appearance of bias in international investment arbitrators and analysis of potential impediments to bias in the European Union's proposal for a multilateral investment court
}

\author{
GEORGE CADILLAC \\ University of Canterbury, New Zealand \\ Email: George@Cadillac.co.nz
}

\begin{abstract}
International investment arbitration is in a controversial state. While the systems put into place by various treaties allow an investor to protect their investments directly by initiating proceedings against a government, claims of arbitrator bias are supported by the fact that arbitrators are appointed by the parties. There are transparency concerns which contribute to arbitrators being biased towards investors from developed countries. The regime of international investment arbitration is heading towards either abolition or reform. The European Union, being the partner to more investment treaties than any other country, proposes the creation of a multilateral investment court. As a structured arbitration court, there may be less bias than the current regime of investment arbitration as proceedings would be more transparent and open to the public, binding precedent would leave less grey area in decisions and add consistency to rulings, and judges no longer being appointed by the parties removes any incentive to rule in favour of their appointing party to secure future appointments. Together with an appeals system, this proposed structure purports to be a positive change in ISDS. However as the essay will show, this approach is not likely to be attractive to the majority of states who are interested in protecting their right to govern. These issues will need to be addressed if the investment court proposal is going to gain support.
\end{abstract}

Keywords: International Investment Arbitration, Bias, Multilateral Investment court, European Union, Investor-State Dispute Settlement

\section{Introduction}

International arbitration is an interesting legal and practical area of the law. While countries may consent in a treaty to hear any investor-state dispute at a neutral tribunal (usually following the rules of either the Washington Convention, UNCITRAL, or other specialised institutions like the permanent court of arbitration) the fact is that governments often dislike losing control of the proceedings. An investment dispute may be heard far away from the state or investor's home, by arbitrators who may not have full knowledge of the parties or the business. Particularly since 2007 there has been growing concern and controversy from central governments over the perceived lack of legitimacy, transparency and neutrality of arbitral institutions and the investorstate dispute settlement (ISDS) system as a whole. This is especially concerning when cases gain significant public notoriety and decisions ought to consider public policy or 
environmental concerns that are unrepresented. These disputes typically begin with an investor claiming that a country, by passing laws or regulations, has breached its obligations under an investment treaty. Because international investment arbitration can be seen as 'second-guessing' or being sovereign over the regulatory actions of governments, the balance between state sovereignty and protecting the legitimate expectations of investors must be maintained. This delicate balance can be upset by concerns of illegitimacy in arbitral tribunals arising from investor bias. Cases like Phillip Morris Asia v Australia ${ }^{1}$, where Australia's anti-smoking regulations harmed the profits of a foreign cigarette company, and Vattenfall $\mathrm{v}$ Germany ${ }^{2}$, where Germany's move away from nuclear power damaged overseas investments, highlight the delicate balance in question and the discreet manner in which such disputes ought to be approached. The appearance of bias can harm the legitimacy of arbitral institutions but also implicates the ISDS system as a whole. Solving the problem of bias will enhance the legitimacy and trust in the system. Some organisations have called for substantial reform of the ISDS. Other entities, such as the European Union, propose a total replacement of the investment arbitration system.

This essay will outline the current controversial state of international investment arbitration with the aim of solidifying the key concerns that there is bias or the appearance of bias in the current system of investment arbitration. It will first examine studies that indicate there is an appearance of bias in international investment arbitration, and explore how this appearance has influenced state governments. It will then examine the European Union's proposal for a multilateral investment court and explore some ways in which its design would make it more neutral, unbiased and legitimate while examining potential illegitimacies and biases that may arise.

\section{The appearance of bias in international investment arbitration.}

The question of whether there is bias in the system of ISDS or whether it is merely an appearance of bias is the first step on the road to improving the legitimacy of the ISDS system. Even the appearance of bias can damage the legitimacy of arbitral institutions in the eyes of governments, academics and the general public. A further question is who the bias favours. There is a growing suspicion of unjust favour to investors, particularly those from developed countries, over states 3 . Because arbitrators in ISDS are typically nominated by the parties, the arbitrators can gain a reputation for being either investor-friendly or host state-friendly as they are motivated to secure future appointments. The effect of bias can have significant effects on the outcome of a case. One study estimates that if an investor is a national of an advanced economy and has had experience working in government, they are $25 \%$ more likely to receive an award of damages 4 . However studies are split on whether bias actually exists. One claims that statistics show arbitrators to favour claimant investors, particularly investors from developed western states, over respondent states ${ }^{5}$. However another study failed to

\footnotetext{
${ }^{1}$ Philip Morris Asia Limited v. The Commonwealth of Australia, UNCITRAL, PCA Case No. 2012-12.

${ }^{2}$ Vattenfall AB and others v. Federal Republic of Germany, ICSID Case No. ARB/12/12.

3 Chin, L, Ho, Jean, Paparinskis, Mārtiňš, International Investment Law and Arbitration: commentary, awards and other materials (Cambridge University Press, New York, 2017) pp75-76.

${ }^{4}$ Strezhnev, A (2016) Detecting Bias in international Investment Arbitration, Harvard University Department of Government.

5 G. V Harten 'Arbitrator Behaviour in Asymmetrical Adjudication: An Empirical Study of Investment Treaty Arbitration’ (2012) Osgoode Hall Law Journal pg 1.
} 
find such a statistical link ${ }^{6}$. Another study conducted by the Kiel Institute examined the claim that arbitrators are biased towards their nominated parties 7 . That study highlighted the fact that the perceived legitimacy crisis of ISDS is often attributed to ad-hoc arbitration tribunals that are composed of arbitrators who, perceived as acting in their own self-interest and under opaque circumstances, are tempted to award in favour of their nominating party. The study used ISDS-related information collected by the United Nations Conference on Trade and Development from over 700 cases, and concluded that the probability of investor wins increases when presidents of arbitration tribunals are 'biased' in the sense that they predominantly served as claimant-appointed arbitrators in previous cases. While the study found this effect to be diminished when arbitrators have more experience, bias remains a concern in many states' assessments of the legitimacy of the ISDS system. The following sections will examine how this distrust in the ISDS system developed, spread and eventually crystallised in actions taken by state governments.

\section{Dissatisfaction in the current state of investment treaty arbitration}

The current state of dissatisfaction in investment arbitration can be traced back to the 1990's. Bilateral investment treaties (BIT's) were being adopted the world over for their uses in diplomatic relation, political publicity and enabling foreign investment. An early sign of the backlash to arbitration was in 2001 when the USA, Canadian and Mexican authorities issued a binding interpretation of the North American Free Trade Agreement. This clarified, among other things, that the minimum standard of treatment to be afforded to investors under the agreement was to be the minimum standard prescribed by customary international law and the standard of Fair and Equitable treatment afforded to investors need not exceed this minimum standard 8 . This was in response to several claims under section 11 that were ruled in favour of the investor, such as Pope \& Talbot' 9 . These cases found that 'fair and equitable treatment' encompasses a much broader area than originally intended by the state parties ${ }^{10}$. This rebalance demonstrates a conscious change by governments to move power away from investors in favour of enhancing a state's right to regulate. While the reasons for this rebalance were partly in response to claims filed against the USA, there were also nonpolitical reasons for the rebalancing. As Charles Brower discusses, the Fair-Trade Commission (a body set out by the NAFTA and composed of representatives of the state parties) issued the binding interpretation in response to interpretive questions arising from vagueness in the original agreement ${ }^{11}$. This change was enhanced when the USA created a new model BIT in 2004. As Judge Schwebel explains, this new model represented a significant change in their foreign policy when compared with their previous 1984 model BIT ${ }^{12}$. The USA now offered less far-reaching protections to

\footnotetext{
${ }^{6}$ S.D Franck 'Development and outcomes of investment Treaty Arbitration' (2009) 50, Harvard International Law Journal pp439, part V.

7 J. Donaubauer, E. Neumayer, P. Nunnenkamp 'Working paper; Winning or losing in investor-to-state dispute resolution: The role of arbitrator bias and experience' (2017), Kiel Working paper, No. 2074, Kiel Institute for the World Economy (IfW) pp. 2-3.

${ }^{8}$ Notes of Interpretation of Certain Chapter 11 Provisions (NAFTA Free Trade Commission, July 31, 2001) s2

9 POPE \& TALBOT, INC. v. HAWN(1953) No. 13

${ }^{10}$ See also Metalclad Corporation v. The United Mexican States, ICSID Case No. ARB(AF)/97/1

, \& S.D Meyers Inc v Canada UNCITRAL (1976).

${ }^{11}$ Charles H. Brower, II, Why the FTC Notes of Interpretation Constitute a Partial Amendment of NAFTA Article 1105, 46 VA. J. INT'L L. 347 (2006).

${ }_{12}$ Schwebel, S, Keynote address at the Tweltfh ITF Public Conference London, 15 May 2009, British Institute of International \& Comparative Law.
} 
investors and instead promised to provide no more than what was customarily provided in international law. This was in stark contrast to the 1984 model, as the minimum standard offered by customary international law became the maximum amount of protection instead of the minimum. The 2004 model replaced the usual substantive protections offered with a minimum standard of which there is no official consensus. While this was an attempt to narrow the scope of protection it remains vague. This vagueness allows for conflicting interpretations at arbitration tribunals, which could provide opportunities for bias to manifest.

By 2007 this official dissatisfaction with the system of ISDS had spread outside the USA. Academics, reporters and arbitrators suggested that this spread was enhanced not only by the substantive protections that treaties provide but also by the procedural behaviour of arbitral tribunals ${ }^{13}$. Criticism by academics of the procedural and substantive rules contributed to the perception that the investment arbitration regime was unfit ${ }^{14}$. Another factor related to the bias is that the arbitration tribunals were often carried on in secret when there were numerous public policy considerations that ought to be heard. This alleged lack of democratic accountability gave rise to a growing concern that international arbitration was losing its edge over domestic courts, contributing to its insufficient legitimacy. Another symptom and result of this perceived lack of legitimacy was the denunciations of the ICSID convention, first by Bolivia in 2007, and soon followed by Ecuador in 2010 and Vanuzuela in 2012. The reasons for this were the alleged bias, lack of an appeals mechanism and the confidentiality of the ICSID proceedings ${ }^{15}$. Soon after states began to terminate their BIT's. In 2012 South Africa began to terminate its European BIT's. In 2014 Indonesia announced its intention to terminate its BIT with the Netherlands and added that it would no longer conclude investment treaties. These terminations offer investor protections in their termination provisions, usually lasting for ten years ${ }^{16}$. It should also be noted that there is a thin line between outright termination and renegotiation. However for the most part, treaties were usually terminated in accordance with their termination provisions, providing for continued investor protection after termination. Dissatisfaction with international investment arbitration is seen worldwide in official circles and seems to be based on perceived illegitimacy arising from confidential proceedings and systemic bias, and manifests in withdrawal from arbitration and investment treaties altogether.

\section{IV: Attempts to 'fix' the arbitration regime}

There have been attempts to 'fix' the arbitration regime. Transparency has improved with the introduction of amicus curiae briefs submitted by the public. NAFTA also began to hold public hearings ${ }^{17}$. However pleadings and decisions often remained confidential, making meaningful public participation difficult. This reduces the transparency of the proceedings and gives rise to the possibility of bias. Another attempt to reduce bias was seen with the creation of the US 2012 model BIT, which was

\footnotetext{
${ }_{13}$ As 3, p 483 .

${ }^{14}$ M. Waibel , A. Kaushal, L. Kyo-Hwa Chung and C. Blachin, 'The Backlash against Investment Arbitrtations: Perceptions and Reality' in M. Waibel, A. Kaushal, L. Kyo-Hwa Chung and C. Blachin (eds), The Backlash against Investment Arbitration (The Hague: Kluwer Law International, 2010), xxxvii-xxxviii, xl-xli, xlix.

${ }_{15} \mathrm{M}$. Sornarajah, Resistance and Change in the International Law on Foreign Investment (Cambridge University Press, 2015), pp 399-400.

${ }^{16}$ A Carska-Sheppard, 'Issues Relevant to the Termination of Bilateral Investment Treaties' (2009), 26 J Int'l Arb. $755,755-756,758-759,761-763$.

${ }^{17}$ As 14 .
} 
intended to be more protective of the host government's regulatory authority and discretion. The new features in the 2012 model make the burdens imposed on governments and the defences available clearer, and add new language regarding issues of public concern such as labour and environmental issues ${ }^{18}$. It also creates better public awareness and participation in proceedings. All of these new features represent a positive change in treaties that 'flesh out' the protections by adding more specific and clarifying language. New treaty rules that have since emerged have seen a trend of being more specific while still allowing for certain flexibility. An example is the 2016 rebalance of the Comprehensive Economic and Trade Agreement (CETA). The new agreement contained clauses that spelled out specifically what the characteristics of fair and equitable treatment are, which reflected many of the bases for usual claims of breaches of that standard ${ }^{19}$. It also spelled out what, exactly, would constitute a breach of an investor's legitimate expectations ${ }^{20}$. It is also suggested that China is making its new generation of BIT's adhere to international standards, which makes the rules more certain ${ }^{21}$. Procedural innovations have also developed, and include penalisation of frivolous claims, introduction of bespoke arbitrator rules of conduct, and adherence to the UNCITRAL Rules on Transparency ${ }^{22}$. The rules on transparency represent a shift from the presumption of privacy in ISDS to one of openness 23 . These changes demonstrate a continued attempt by states to clarify the standards of protection in an attempt to remove any potential for bias or conflicts of interest. If this trend continues it is possible that these reforms would be sufficient to minimise bias.

\section{European Union proposal for a multilateral investment court}

The European Union is in an, at least informally, authoritative position when it comes to ISDS and investment treaties. Germany and Pakistan concluded the first BIT, and EU member states are partner to many existing BIT's. The European Union already provides for appellate mechanisms, which would enhance predicability and coherence ${ }^{24}$, in their investment treaties since 2004. While these have not been vigorously implemented there is always the possibility that they will be included in a multilateral investment court system in the future. The European Union proposes replacing international investment arbitration with an international investment court'. This would likely be adopted in the EU's current and future investment agreements. A communication by the European Commission identified transparency, consistency, predictability and the possibility to appeal as challenges that would be addressed in the EU's investment policy ${ }^{25}$. Improvement in each of these areas would potentially reduce bias. To these ends, and following growing concern about the perceived insufficient legitimacy, neutrality and transparency of ISDS, the EU proposed the replacement of ISDS with an Investment Court System (ICC). This would

\footnotetext{
${ }^{18}$ L. Johnson, 'The 2012 US Model BIT and What the Changes (or Lack Thereof) Suggest about Future Investment Treaties', Political Risk Insurance Newsletter, vol. VIII, Issue 2, November 2012.

19 CETA (2016) Art. 8.10(2)(a)-(f).

${ }^{20}$ As 19, Art. 8.10(4).

${ }^{21}$ W. Shan, H, Chen, 'China-US BIT Negotiation and the Emerging Chinese BIT 4.0' in C.L. Lim (ed.), Alternative Visions of the International Law on Foreign Investment (Cambridge University Press, 2016), 223, 238. 
have a first instance and appeal tribunal, permanent judges appointed by the EU and its investment partners, and work openly and transparently ${ }^{26}$. The EU has had this policy since 2014, and multilateral ISDS mechanisms have been provided for in the CETA and the Vietnam-EU FTA. One factor that would reduce bias is the quality and appointment of the judges in the MIC. The TTIP provisions which would likely be mirrored in the MIC state that judges are bound to strict codes of conduct and must be independent and unbiased ${ }^{27}$. There is also a mechanism available for parties to raise possible conflicts of interest. The decisions of the MIC would presumably be open to any countries. This presents an issue when multilaterally enforcing strictly bilateral yet similar agreements. Countries that have previously shown a reluctance to adhere to multilateral agreements may be reluctant to submit to a court that operates on precedent regarding different agreements. The MIC also consolidates power to states, potentially making the court more biased in favour of host states. However as Roberts suggests, this particular notion of bias results from a view of states as host states rather than the more accurate perception of states as treaty parties that have an interest in investor protection also ${ }^{28}$. Another issue is that an imposed MIC would remove competition in the free market and result in stagnation. However if the MIC turns out to be unpopular states are free to negotiate an exit from its jurisdiction.

\section{Conclusions}

While the appellate mechanism, codes of conduct and overseas enforcement features of the proposed MIC are likely to address the growing concern of bias, conflict of interest, and insufficient legitimacy in ISDS, the fact is that the proposed features could be implemented into the existing system without having to upend it completely. This alternative approach would likely be more attractive to state governments sharing the concern that ISDS is in need of reform.

\section{References}

Carska-Sheppard, A .'Issues Relevant to the Termination of Bilateral Investment Treaties' (2009), $26 \mathrm{~J}$ Int'l Arb.

Chin, L, Ho, Jean, Paparinskis, Mārtiṇš, International Investment Law and Arbitration: commentary, awards and other materials (Cambridge University Press, New York, 2017)

Donaubauer, J. , E. Neumayer, P. Nunnenkamp 'Working paper; Winning or losing in investor-to-state dispute resolution: The role of arbitrator bias and experience' (2017), Kiel Working paper, No. 2074, Kiel Institute for the World Economy (IfW)

Franck, S.D ‘Development and outcomes of investment Treaty Arbitration’ (2009) 50, Harvard International Law Journal

Harten, G. V 'Arbitrator Behaviour in Asymmetrical Adjudication: An Empirical Study of Investment Treaty Arbitration' (2012) Osgoode Hall Law Journal

\footnotetext{
${ }^{26}$ European Commission, 'The Multilateral Investment Court Project', Brussels, 21 December 2016.

${ }^{27}$ Art. 11, Annex 2.

${ }^{28}$ A. Roberts (2017) 'Would a Multilateral Investment Court be biased? Shifting to a treaty party framework of analysis', IELP.
} 
Johnson, L. 'The 2012 US Model BIT and What the Changes (or Lack Thereof) Suggest about Future Investment Treaties', Political Risk Insurance Newsletter, vol. VIII, Issue 2, November 2012

Johnson, L. N. Bernasconi-Osterwalder, 'New UNCITRAL Arbitration Rules on Transparency: Application, Content and Next Steps' (CIEL, IISD, CCSI, August 2013

Karl, J. 'An Appellate Body for International Investment Disputes: How Appealing Is It?', Columbia FDI Perspectives, No. 147, 11 May 2015

Philip Morris Asia Limited v. The Commonwealth of Australia, UNCITRAL, PCA Case No. 2012-12

Roberts (2017) 'Would a Multilateral Investment Court be biased? Shifting to a treaty party framework of analysis', IELP

Roberts, A. \& T. St-John ‘UNCITRAL and ISDS Reform: In Sickness and In Health’ (2019) IELP

Roberts, A. 'Would a multilateral Investment Court be Biased? Shifting to a treaty party framework of analysis' (2017) IELP

Schwebel, S, Keynote address at the Twelfth ITF Public Conference London, 15 May 2009, British Institute of International \& Comparative Law

Shan, W. H, Chen, 'China-US BIT Negotiation and the Emerging Chinese BIT 4.o' in C.L. Lim (ed.), Alternative Visions of the International Law on Foreign Investment (Cambridge University Press, 2016)

Sornarajah, M. Resistance and Change in the International Law on Foreign Investment (Cambridge University Press, 2015)

Strezhnev, A (2016) Detecting Bias in international Investment Arbitration, Harvard University Department of Government

Vattenfall AB and others v. Federal Republic of Germany, ICSID Case No. ARB/12/12

Waibel, M. , A. Kaushal, L. Kyo-Hwa Chung and C. Blachin, 'The Backlash against Investment Arbitrations: Perceptions and Reality' in M. Waibel, A. Kaushal, L. KyoHwa Chung and C. Blachin (eds), The Backlash against Investment Arbitration (The Hague: Kluwer Law International, 2010), 